\title{
THE ENGINEERING EXPERIMENT STATION OF THE UNIVERSITY OF ILLINOIS
}

\author{
BY ELLERY B. PAINE
}

\section{Abstract of Paper}

The bulletins published by the Engineering Experiment Station of the University of I1linois containing the results of the research investigations made at the University have attracted wide attention. The paper describes the organization for engineering research at the University of Illinois. The nature of the investigations undertaken is discussed. A description is given of the equipment available for experimental work. Lantern slides will be used in presenting the paper. These illustrate the research facilities of the station and the methods used in experimental work.

$\mathrm{T}$ HE ENGINEERING Experiment Station of the University of Illinois was established by action of the Board of Trustees in December, 1903. It was organized as one of the auxiliary scientific bureaus of the University. Its purposes are the stimulation and elevation of engineering education and the investigation of problems of especial importance to professional engineers and to the manufacturing, railway, mining and industrial interests of the state and country. The Station is conducted as an institution of scientific research rather than as a commercial testing laboratory. Investigations are chosen which promise information of fundamental importance in the particular field. No researches are undertaken with the object of obtaining information of chief value to some individual or company. The results of the investigations, that yield data of scientific value, are given to the public in the form of bulletins.

The control of the Station is vested in the Station Staff, which consists of the Director and the Heads of the ten Departments of the College of Engineering. Research is made in Architectural Engineering, Chemistry, Ceramic Engineering, Civil Engineering, Electrical Engineering, Mechanical Engineering, Mining Engineering, Municipal and Sanitary Engineering, Physics, Railway Engineering, Theoretical and

Manuscript of this paper was received September 9, 1915. 
Applied Mechanics. The investigations are conducted under the supervision of the staff by members of the instructional staff of the College of Engineering, by Experiment Station special investigators and by Experiment Station research fellows. There are 103 members of the instructional staff in the College of Engineering. They must devote the major portion of their time, while the University is in session, to class-room duties, but each is encouraged to take an active part in some research. There are nine special investigators. They have no duties connected with student instruction but give their full time to station work. They are experienced and skilled research workers. There are fourteen research fellows. The fellows devote half their time to station work and half their time to study in the Graduate School of the University. They are graduates of approved technical schools and universities who have shown ability for experimental work. Fellows are appointed for a term of two years and it is expected that at the end of that period they will be eligible for the degree of master of science.

The laboratories of the University are available for the investigations of the Station. In addition to the equipment used largely for student instruction the laboratories contain apparatus designed especially for research work.

The cement laboratory is provided with moulding machines, testing machines and other apparatus for determining the properties of cement.

The road laboratory contains machines for testing the resistance of macadam material to impact and abrasion. It also contains devices for testing paving materials, oils, tar and asphalt.

The electrical engineering laboratory is located in a two-story brick building with a floor area of 18,000 sq. ft. It receives direct current, two-phase and three-phase electrical energy from the $500 \mathrm{kw}$. power plant of the University. The laboratory contains $45 \mathrm{~d}$-c. dynamos with total capacity of $400 \mathrm{kw} ., 25 \mathrm{a}$-c. dynamos with total capacity of $325 \mathrm{kw}$., and 45 transformers with total capacity of $375 \mathrm{kw}$. The instrument room contains standards for the calibration of all types of commercial instruments and also about 300 portable instruments for experimental work. There is available a 60-cell 240 amperehr. storage battery for work necessitating steady current. A 200,000 volt transformer affords opportunity for high-voltage a-c. testing. A set of 30 small d-c. generators is installed with series electrical connection of the machines for high-voltage 
direct-current experiment. From this set potentials up to 20,000 may be obtained. The current capacity of these machines is half an ampere. The electrical furnace room contains one $30-\mathrm{kw}$. induction furnace, one $25-\mathrm{kw}$. arc furnace, two $20-\mathrm{kw}$. induction furnaces, one $15-\mathrm{kw}$. vacuum furnace for melting; one $30-\mathrm{kw}$. vacuum furnace for annealing and one $1.5-\mathrm{kw}$. muffle furnace. Four oscillographs are available for the study of transient electrical phenomena. A department shop in charge of a skilled mechanician is located in the basement of the electrical building. In this shop is constructed a large part of the special apparatus needed in the electrical researches of the Station.

The mechanical engineering laboratory is located in a brick building with floor area of $24,000 \mathrm{sq}$. $\mathrm{ft}$. The main bay of the laboratory has a concrete testing floor and is served by a 10-ton electric traveling crane of 38 - $\mathrm{ft}$. span. The laboratory is equipped with machines and testing instruments for research in steam engine ring, gas power engineering, refrigeration, heating and ventilation. This laboratory contains a 210 h.p. boiler with chain grate stoker, arranged especially for fuel tests. There are a number of types of throttling, high-speed automatic and Corliss steam engines; several gas, gasoline, and oil engines; several steam turbines; a compound two stage air compressor; a 10-ton ammonia refrigerating machine; and several house-heating furnaces and boilers.

The shop laboratories are located in two brick buildings with a combined floor area of $28,000 \mathrm{sq}$. $\mathrm{ft}$. The wood shop is equipped with benches, machinery and small tools needed in pattern work. The foundry has a mounding floor 35 by $80 \mathrm{ft}$. traversed by a 5 -ton traveling crane. The foundry is equipped with cupola, brass furnaces, core ovens, moulding ma'chines and facilities for bench and floor moulding. The forge shop contains forges, anvils and small tools, a steam hammer, a power driven punch and shear, and gas and electric furnaces. The machine shop has a floor 48 by $140 \mathrm{ft}$. A three-ton traveling crane serves the central section of the shop. The machine shop is equipped with lathes, planers, shapers, milling machines, grinders, boring mills, drill presses and with typical small tools used in manufacturing. The shop laboratories contain auxiliary apparatus necessary for investigation of machine tools and shop processes.

The laboratory of applied mechanics comprises the materials testing laboratory and the hydraulics laboratory. It is located in a brick building with floor area of 16,000 sq. $\mathrm{ft}$. The materials 
testing laboratory contains a testing machine of 600,000 pounds capacity designed for large and bulky specimens. It also contains several other machines of large capacity for testing full size structural members. The laboratory contains a mechanician's workshop. A large room in an adjacent building is available for the preparation of concrete specimens for test. The hydraulics laboratory has facilities for furnishing water under a large range of pressures. The equipment includes measuring pits, water meters, weir channels, nozzles and other apparatus for measuring the flow of water. The laboratory contains pumps of various types, several water motors and a turbine water wheel for testing purposes.

The locomotive testing laboratory occupies a brick structure with floor area of $5000 \mathrm{sq}$. ft. The testing plant consists of supporting wheels on which rest the drivers of the locomotive to be tested, water brakes for absorbing the power developed by the locomotive, a dynamometer for measuring the tractive forces developed by the locomotive and other auxiliary apparatus. The exhaust gases are led to a reinforced concrete separator where the cinders are removed. Locomotives to be tested are brought to the laboratory over a spur connected with the Illinois Traction System tracks. The ultimate capacity of this laboratory is sufficient for the test of the largest locomotives now in use. Certain western railroads cooperate in the locomotive performance investigations and furnish the locomotives to be tested. The University owns and operates, jointly with the Illinois Central Railroad, a railway test car designed for experimental work on steam roads. During the last twelve years this car has been in frequent operation in making resistance and tonnage rating tests on the Illinois Central Railroad and on several eastern roads. The University also owns an electric test car of the interurban type designed especially for experimental work. It is equipped with four 50-h.p. d-c. motors and with instruments for recording power, speed, acceleration and other data needed in road tests. Under an arrangement with the Illinois Traction System the test car may be operated on its lines. The equipment available for special investigation of railway problems also includes a drop-testing machine for testing the strength of railroad rails, car axles, draft gears and structural materials of various sorts and a brake-shoe testing machine for determining the wearing properties and frictional qualities of brake shoes.

The mining and ceramics laboratories occupy a one-story 
brick building with floor area of 11,200 sq. $\mathrm{ft}$. The mining laboratory is well equipped for the study of safety lamps and for gas and dust analysis and explosibility tests. It also contains machinery for ore dressing and coal washing, including rolls, crushers, stamps, screens and jigs. There are also a complete sampling and drying equipment, a Huff electrostatic machine and other testing apparatus. The kiln room in the ceramics laboratory has a floor area of $4300 \mathrm{sq}$. $\mathrm{ft}$. In addition to kilns of various types this laboratory contains apparatus for scientific investigations of problems of great importance to the ceramics industry. A ceramics building is under construction at the University of Illinois. When it is completed and equipped it will afford unsurpassed opportunities for research in ceramic engineering.

The laboratory of physics occupies a three-story brick building with floor area of 60,000 sq. ft. The laboratory contains over 4000 pieces of apparatus for instruction and for advanced work. The building contains about 30 rooms especially adapted to research work. The building has a workshop for the use of the research investigators; also a mechanician's work-shop equipped for work of precision.

Investigations are undertaken only after a careful consideration of the information published which bears on the problem, the facilities at hand for the investigation and the probability of obtaining new information of value to the engineering profession. In some cases committees of men prominent in engineering or industrial circles have been appointed for conference and advice concerning the investigational work of the Station. All investigations undertaken by the Engineering Experiment Station are carried on in the interest of scientific knowledge and the acquirement of data upon which engineering design may be based. It is not possible for the Engineering Experiment Station to make investigations which involve great expense for apparatus or materials without the cooperation of individuals or organizations who are sufficiently interested in the results to aid in the work. Whenever the cooperative investigation of an important problem appears desirable the Station is ready to offer its facilities for the work.

Perhaps the most noteworthy researches carried out by the Experiment Station are those which have developed into a series of investigations of different phases of large problems. As instances of such work of wide scope may be mentioned the 
investigation of reinforced concrete in the Laboratory of Applied Mechanics, the investigation of coal in the laboratories of Chemistry and of Mechanical Engineering, the investigation of steam locomotive performance in the Locomotive Laboratory and the investigation of the magnetic properties of iron alloys in the Electrical Engineering Laboratory.

Experimental work for private parties is sometimes carried on in the engineering laboratories of the University of Illinois but only in cases where the results obtained give promise of scientific interest or in cases where the facilities at the University make it especially desirable that the tests be made at the University.

On the completion of an investigation, manuscript for a proposed bulletin is prepared incorporating the results of the investigation. The manuscript is considered by the Station Staff and in case it is deemed to be of sufficient merit it is published. Eighty-two bulletins have been issued by the Engineering Experiment Station of the University of Illinois. They are sent to those who indicate they are interested. The mailing list contains 8000 addresses scattered throughout the civilized world.

The influence of the Engineering Experiment Station is stimulating to engineering instructors and to engineering students through the atmosphere of engineering research and investigation which it brings. The work of the Experiment Station directs the attention of engineering students to some of the problems for which engineers desire the solution. Although the students usually take no active part in the Experiment Station work yet the opportunity to observe the methods used in engineering research may be of great value to them.

The work of the Engineering Experiment Station has been of great aid to professional engineers and to various industrial interests. The train and locomotive tests conducted by the Experiment Station have resulted in a change in practice on some railways. The investigations made in the Laboratory of Applied Mechanics of the University of Illinois have had a very marked effect on the art of reinforced concrete construction. The results of the tests on reinforced concrete beams, columns, slabs and pipes have been utilized by the leading committees and makers of codes in the formation of requirements and regulations for building construction. Committees of engineering societies have utilized the work of the Experiment Station in 
connection with investigations of brick, concrete, steel and other materials. The Engineering Experiment Station bulletins have been extensively quoted by the compilers of hand-books and by other engineering and scientific writers in this country and abroad. Many other similar instances might be mentioned which indicate that the investigations of the Enginering Experiment Station of the University of Illinois are of value to professional engineers and to the various industrial interests of the state and country. 